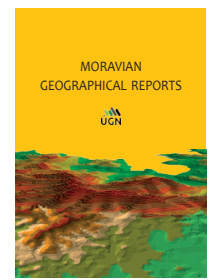

MORAVIAN GEOGRAPHICAL REPORTS

\title{
The countryside in the city? Rural-urban dynamics in allotment gardens in Brno, Czech Republic
}

\author{
Lucie SOVOVÁ a *, Radoslava KRYLOVÁ a
}

\begin{abstract}
The position of urban allotments in the rural-urban spectrum is evaluated in this paper, which contributes to literatures on urban gardening, as well as contemporary rural-urban dynamics. Historically, European allotments can be seen as a product of urbanisation. At the same time, they embody a number of "non-urban" characteristics that create the impression of "the countryside in the city". This research project investigates how the urban and the rural are materialised, represented and practised in five allotment sites in Brno, Czech Republic. We follow three main lines of enquiry where the urban and the rural seem to meet: the physical environment of the allotments; the social life of these spaces; and food production as one of their core functions. Critical reflection of the rural-urban perspective advances our understanding of urban gardens, while, at the same time, allotments offer an example of hybrid spaces, which, in turn, contribute to discussions on current cities and countrysides. Overcoming the urban-rural dichotomy could facilitate the inclusion of urban gardening in contemporary cities.
\end{abstract}

Keywords: urban gardening; allotment; rural-urban dynamics; counterurbanisation; food self-provisioning; new sociations; Brno; Czech Republic

Article history: Received 8 July 2018, Accepted 14 March 2019, Published 30 June 2019

\section{Introduction}

In recent decades, the world has become increasingly urban-centred, and the countryside has acquired new features and meanings. For the first time in human history, the majority of the world's population now lives in urban areas (UNPF, 2007). In some regions, the global economy has decreased the importance of the countryside as a place of production (Horlings and Marsden, 2014). The loss of fertile soil, agricultural land and the 'natural' landscape has created a hybrid peri-urban interface (Allen, 2003).

Scholars have been following rural-urban dynamics, and developing new concepts for hybrid forms of ruralurban blends. The changing role of the countryside has been addressed by rural sociologists (as summarised by Granberg, 2016), and "the consequences of a sprawling urbanism have emerged as theoretical objects in urban planning, critical human geography and anthropology"
(Vasantkumar, 2017, p. 368). Rather less attention has been paid, however, to alternate trajectories in which the rural "spills out" into the city (ibid.).

Urban agriculture could be seen as an example of such dynamics, as it places food production in urban locations and in close connection to urban economic and ecological systems (Mougeout, 2000; van Veenhuizen, 2006). In the last two decades, diverse ways of producing food in cities have attracted growing attention from both scholars and practitioners. This paper uses insights from urban agriculture scholarship to add a new perspective to the ongoing discussion about the changing nature of cities and countryside, and the different ways of conceptualising these dynamics. We investigate the rural-urban intersections implied by the term urban agriculture, using the example of allotment gardens ${ }^{1}$ in Brno, Czech Republic. As we will elaborate, this form of urban gardening has a long tradition

\footnotetext{
${ }^{a}$ Department of Environmental Studies, Faculty of Social Studies, Masaryk University, Brno, Czech Republic (*corresponding author: L. Sovová, e-mail: sovova@mail.muni.cz)
}

\footnotetext{
${ }^{1}$ We understand the term allotment gardens to mean parcels of land divided into smaller plots that are used by individuals. Thus, allotments differ from community gardens in which a group of people cultivates a shared piece of land together. Some authors, however, conflate these terms, including allotments under the heading of community gardens (e.g. Veen, 2015; Okvat and Zautra, 2011). Both allotment gardens and community gardens can be categorised as types of urban gardening, together with home gardens in the city, guerrilla gardening and other forms of non-professional food growing in urban settlements. Urban agriculture is a broader term that covers both private and commercial food production practised in cities.
} 
in Europe (Tóth et al., 2018). At the same time, researching allotments is relevant from the perspective of urban planning and policy because they are often located on public land.

In this paper, we present urban allotments as spaces that are physically located in cities but which feature several rather "non-urban" characteristics. Researchers of Czech urban allotments have already pointed out that these urban gardens do not in fact seem urban at all. Klvač and Ulčák note that urban allotments are in a way more "rural" than the countryside itself, where vegetable beds are gradually being replaced by swimming pools, lawns and other features associated with urban lifestyle (Klvač and Ulčák, 2008; Klvač, 2013). Following upon these observations, we investigate how the rural and the urban manifest and interact in urban allotments. Specifically, we explore three main areas where the urban and the rural seem to meet: the physical environment of allotments; the social life of these spaces; and food production as one of their core functions. The rural-urban lens offers a novel perspective that advances our understanding of urban gardens.

The paper is structured as follows. Section 2 briefly outlines some of the perspectives on the rural and the urban as analytical categories used in this paper. In section 3 , we refer to existing literature on urban gardens as green environments (3.1), places of social interaction (3.2) and food production sites (3.3). We use a chronological perspective, discussing the relation of gardens to the city since their (European) origins at the end of the nineteenth century to the present, and the evolution of their three afore-mentioned functions during this time. After presenting our research methods in section 4, we follow up on the environmental (5.1) social (5.2) and productive (5.3) dimensions of urban allotments, by introducing and discussing the results of our study. Our conclusions are summarised in section 6.

\section{Changing meanings of the rural and the urban}

The city and the countryside have undergone significant changes, and scholarly understandings of the rural and the urban have become increasingly complex and contested. This section aims to briefly introduce some of the main developments in the ways of being of, and discourses about, the city and the countryside, which inform our approach in this paper.

Vasantkumar (2017) summarises some of the operational definitions of the rural and the urban, which include demographic and economic variables. In terms of population density and distribution, the countryside can be defined as spaces with relatively lower concentration of a human presence, whereas urban settlements are characterised by higher densities of inhabitants. In terms of modes of production, the countryside has been associated with agriculture and other activities in which humans engage directly with the natural environment (e.g. natural resource extraction, and more recently also tourism). Cities, on the other hand, have been understood as places where the countryside's products are processed, and where industry, services and knowledge-based sectors predominate (Cloke, 2006; Andersson et al., 2016, chap. 1). While such spatial and functional descriptors are still used, they have become less reliable with the spatial hybridisation of the urban and the rural observed from the twentieth century to the present.

According to Gandy (2010), the early modernist city was easily distinguished from the countryside because both were defined as their own political and economic entities. During the twentieth century, the industrial city expanded into the countryside, "corrod[ing] and dissolv[ing] it" (Lefebvre, 1996, p. 119), by weakening its specific peasant features and producing a new type of "rurban" space (ibid, p. 120). The boundaries between the city and the countryside have been blurred by suburbanisation and urban sprawl, the scope of which varies from region to region (see e.g. Sýkora, 2014; Oueslati et al., 2015). While urbanisation remains the most prevalent trend globally, some regions - including the Czech Republic - are also witnessing the inverse processes of urban shrinkage (Haase, 2008; Rumpel and Slach, 2012), and migration to the countryside, termed counterurbanisation (Andersson et al., 2016, chap. 1; Berry, 1976; Šimon and Bernard, 2016). This migration pattern is mostly assumed to be driven by lifestyle choices, although economic necessity can play a role as well (Mitchell, 2004).

Rural and urban societies and lifestyles have evolved in parallel to changes in the physical environment and the economy. Modernist social theorists saw rural societies as conservative and dependent on traditional knowledge and strong social bonds. Cities, on the other hand, embodied progressive worldviews, expert knowledge and the concentration of political power (Granberg, 2016; Vasantkumar, 2007). Urban lifestyles granted more anonymity and individual freedom, which relates to the process of individualisation (Novák, 2013, p. 16) ${ }^{2}$. Changes in rural and urban forms and the mingling of urban and rural populations challenge the commonplace characteristics of urban and rural societies, particularly as urban lifestyles have gradually penetrated the countryside.

Some authors therefore understand urbanisation not only as the physical expansion of cities, but also as the adoption of stereotypically urban lifestyles regardless of where people live (Champion, 2001, p. 144). In a similar vein, Andersson et al. (2016) also link counterurbanisation to an increased interest in nature and the countryside among urban populations. This interest is interpreted as a reaction to individualisation, human-nature alienation and the latemodern search for spiritual and bodily fulfilment (ibid., p. 3). Apart from actual changes in residence, this tendency can manifest itself in rural tourism, an appreciation of local, ecological and healthy food, or the preference of hand- and home-made goods over industrial products (ibid.).

These more nuanced understandings are part of a move beyond modernist social theory, in that some scholars have begun to acknowledge that the seemingly inherent and essential characteristics of the urban and the rural are in fact a product of political-economic power dynamics and the social construction of meaning. In some disciplines, such as geography and critical anthropology, the very notions of the rural and the urban have become contested (Cloke, 2006).

On the other hand, modernist categories of the city and the countryside remain strongly entrenched in

\footnotetext{
${ }^{2}$ Individualisation is conceptualised as one of the main social changes accompanying industrialisation and urbanisation. It entails loosening social roles and cultural norms linked to class, gender, religion and place (Novák, 2013; Librová, 2010). These can be seen as positive developments in terms of personal freedom, but also more critically as the atomisation of society and the loss of support provided by traditional social bonds.
} 
both popular and academic discourses as "apparently commonsensical" (Vasantkumar, 2017) understandings of the rural and the urban. As some authors argue, this is partly due to the fact that the opposition of rural and urban mirrors other sociological dichotomies: the modern and the traditional (Granberg, 2016), culture and nature, the human and the non-human, and the globalised and the localised (Vasantkumar, 2017). These intertwined dichotomies tend to reinforce each other, leading to oversimplification, stereotyping and methodological confusion. What is more, this construction of meaning seems to favour the urban, whereas the rural must settle for a negative definition of "whatever is leftover [sic] after the urban has been identified" (Vasantkumar, 2017, p. 370), or, as Plüschke-Altof (2016) puts it, the rural is conceptualised as periphery.

Rather than maintaining such simplifying dichotomies, we should acknowledge that - as a result of the above-mentioned changes - the city and the countryside create hybrid forms in which both "urbanisation of the rural" and "ruralisation of the urban" occur (Cloke, 2006). A key challenge for scholars is how to conceptualise these hybrid forms in a way that reflects both spatial and social changes.

\section{Allotment gardens as products of (counter) urbanisation}

Allotment gardens have played a specific part in the development of rural-urban relations, and examining their history in Europe is revealing in this sense. The first urban allotments were established at the end of the nineteenth century with the aim of providing factory workers, who had migrated from the countryside, with the opportunity to improve their livelihoods through food self-provisioning. Furthermore, garden plots were to compensate for poor housing conditions and the generally insalubrious living environment typical of the rapidly-expanding and industrialising cities of the era (Keshavarz and Bell, 2016). These gardens also served as a place for workers to spend their free time and carry out activities that were close to their rural identity, and therefore brought a sense of familiarity and belonging (Nilsen and Barnes, 2014). In this section, we discuss how these three functions ${ }^{3}$ of urban allotments have evolved into their present forms.

\subsection{Urban gardens as green environments}

As indicated above, the first European allotments were established in part as a reaction to the poor hygienic conditions in newly-built workers' neighbourhoods. The German branch of the gardening movement (Schrebergarten), in particular, emphasised the health benefits of fresh air and a green environment (Keshavarz and Bell, 2016; Nilsen and Barnes, 2014). Later, urban gardens were embraced by modernist urban planners who experimented with urban greenery - the most pronounced example is Ebenzer Howard's concept of the garden city (Kershavarz and Bell, 2016).
In the twentieth century these ideas resonated with planners throughout the entire continent, not only in Western Europe but also in Central and Eastern Europe. For instance, in the 1970s planning visions for Belgrade, Yugoslavia, public greenery met place-making: "Each household should be granted contact with soil and its creative cultivation. This estrangement from land, grass, flowers, trees, from that to which a concrete man has a personal obligation and responsibility, is one of the important problems both of the concrete-paved center [sic] and the open block of no man's land, grass, and greenery" (Ferenček, 1977, quoted in Djokić et al., 2017, p. 4).

With a more nuanced understanding of environmental issues, discussions about the environmental dimension of urban gardens have expanded. From an ecological perspective, urban gardens constitute a part of urban green infrastructure and a way of ensuring ecosystem services for urban environments (Tóth and Timpe, 2017). As green spaces, gardens reduce the urban heat island effect, capture rainwater and therefore serve as a climate adaptation measure (van Veenhuizen, 2006). They function as local biodiversity hotspots, providing refuge for animals, including pollinating insects. Plants and trees contribute to carbon sequestration, composting alleviates urban waste systems and helps close nutrient cycles ${ }^{4}$. Environmental benefits are also linked to localised food production (Vávra et al., 2018), although some growing methods might be problematic from an environmental perspective, and there is an ongoing discussion about the use of industrial pesticides and fertilisers and gardeners' environmental consciousness (see Sovová, 2015).

Another body of literature describes the health benefits of spending time in green surroundings. The negative impacts of human alienation from nature have been documented in psychology and educational sciences (McClintock, 2010). Okvat and Zautra (2011) list the psychological benefits of urban gardening in both cognitive and affective realms. Prescribing gardening as a remedy to the soul-destroying inner city echoes the narratives of Schrebergarten.

Moreover, urban gardens have been praised as spaces of environmental education. Breuste and Artmann (2014) explain that gardeners often use their plots to observe animals and learn about nature. Some authors even suggest that gardening can foster environmental consciousness. According to Bhatti and Church (2001), for instance, everyday encounters with nature facilitated by a garden can make abstract environmental issues more accessible. In this way, gardens have the potential to contribute to environmental awareness and more sustainable lifestyles (Okvat and Zautra, 2011), although this potential should be assessed critically.

\subsection{Urban gardens as new sociations}

The earliest allotments in Europe were in part founded to occupy factory workers' free time. This was a strategic move on the part of the political and economic authorities: the logic

\footnotetext{
${ }^{3}$ The focus of the first European allotments varied slightly in different countries. For instance, the German allotment movement emphasised healthy environment and outdoor activities (see section 3.1), whereas the French gardening movement stemmed from solidarity with the poor and focused more on food provisioning (Gibas et al., 2013, p. 31).

4 These benefits of green spaces are not unique to cities, but they are often discussed specifically in relation to urban environmental issues. This confirms the persistent association of nature with the countryside. The word "greenery" would rarely be used in a rural context; "rural nature" sounds redundant, for nature is presumably linked to the rural. At the same time, terms such as "urban nature" or "urban wilderness" also carry an inherent tension, suggesting that "nature" and "wilderness" are not typical urban attributes (see also Vasantkumar, 2017).
} 
was that content workers who spent time at their allotments would be less likely to engage in politically radical activities (Nilsen and Barnes, 2014; Novák, 2013). Contemporary urban gardens do not follow this trend; in fact, they are often places that question the status quo (McClintock, 2010; Tornaghi, 2016). At the same time, the social features of urban gardens are still considered important. Urban gardens are praised as places of community empowerment (Okvat and Zautra, 2011), social cohesion (Veen, 2015), and inclusion and integration (Koopmans et al., 2017). They foster urban dwellers' senses of belonging (Djokić et al., 2017), home (Bhatti and Church, 2001) and placemaking (Koopmans et al., 2017).

As Novák (2013) argues, urban gardens can function as "new sociations", that is, as less institutionalised forms of social arrangements (Macnaghten and Urry, 1998, p. 27). Unlike traditional communities, sociations are joined voluntarily and can be left freely. People join them because of the emotional satisfaction resulting from shared goals and social experiences (ibid.). They can bring a new solidarity based on cooperation and sharing. They provide, in sum, a remedy for urban individualisation and alienation. According to Novák, such tendencies are definitely identifiable in the community gardens that have appeared in the United States and Great Britain since the 1970s, which have been established "not only for the purpose of collective cultivation of vegetables but also identity cultivation, community revitalisation and civility" (Novák, 2013, p. 21). Some authors (e.g. Schmelzkopf, 2002) even frame urban gardens as political spaces where urbanites enact their right to the city and civic engagement.

Historically, Czech allotment gardens have developed along a different path. In socialist Czechoslovakia, urban gardening was supported by the state: gardening associations were allocated state-owned land unfit for professional agriculture, and gardeners supplied their surplus produce to regular food chains (Tóth et al., 2018). Despite being controlled by the authorities, allotments were mostly internally apolitical In fact, being one of the few non-politicised spaces, gardens served as places of "internal exile" for many (Duffková, 2002). Novák argues that allotments still enabled gardeners to develop their identities and social relationships, and they thus played the role of new sociations (2013, p. 21).

\subsection{Food production in the city: tradition and alternative}

In the modernist rural-urban distinction, food production was unequivocally placed in the countryside, whereas cities were places of trade and consumption (Koopmans et al., 2017). During the last two decades, however, a growing body of literature on urban agriculture has shown that cities can and should include food provisioning in their agendas. As mentioned, land-use changes and economic diversification together with the depopulation of the countryside and changing rural lifestyles, have challenged the traditional equation of the rural landscape with food production (Duží et al., 2017; Granberg, 2016). At the same time, urbanisation poses numerous logistical issues: although cities are the sites of most of the political and economic power, their basic metabolism is fundamentally dependent upon external supply (Simms, 2008).

These issues were already reflected in the development of allotments at the beginning of the twentieth century, as summarised by Bellows: "Urbanisation required massive adjustments in land and labour. The technicalities of feeding the relocated rural population were largely left to the uprooted peasants. (...) Policy effectively transplanted a 'country' livelihood into the physical design and social expectations of emerging urban areas" (2004, p. 248). Since then, urban gardens have supplied food in times of crisis throughout the world: in the USA and Great Britain during World War II in the form of the 'victory gardens', in Cuba after the decline of food and fuel imports caused by the collapse of the Soviet Union (Simms, 2008), in slum areas in cities of the global South via aid programmes (Voleníková, 2014), and in Southern European cities affected by the 2008 economic crisis (Delgado, 2017).

Furthermore, growing food in cities brings other benefits beyond food security. Urban gardens are linked to the broader search for more environmentally sustainable and socially just ways of producing, distributing and consuming food, known as alternative food networks (AFNs; Renting et al., 2003). AFNs have evolved in reaction to problems inherent in the conventional food system, which is based on industrial agriculture and long supply chains. These initiatives try to offer a more transparent food system, in which the origin and qualities of food are known to consumers. AFNs strive to bring producers and consumers closer not only geographically (i.e. localised food production) but also socially: consumers should be able to know the farmer who produced their food and vice versa, and relations between producers and consumers should be based on trust and solidarity. Thus, AFNs aim to create opportunities for rural development while at the same time addressing the urban dwellers' alienation from food production (ibid.).

We can therefore view AFNs as an incarnation of the 'counterurbanisation ethos': once urban consumers lost trust in standardised industrial products, they began to search out more wholesome food-production alternatives in agriculture's traditional place - the countryside. Indeed, as Andersson et al. (2016, p. 3) note, increased interest in food is one of the manifestations of the urban desire to reconnect with the countryside, as well as one of the vehicles to achieve this reconnection.

As more critical scholars warn, however, interest in transparent, short food-supply chains is at the risk of being reduced to a fetish for distinctiveness (see e.g. Overton and Murray, 2016). The desire of conscientious urban consumers for "food with a story" is driven by nostalgic ideas of the countryside as pure, healthy and home-like. But the same disconnect between the rural and the urban that propels these wishes, also makes it easy for corporations to satiate them by marketing - featuring romanticised images of a countryside that no longer exists, if it ever has.

Urban gardens have the potential to overcome this risk by removing the gap between producers and consumers, and by offering consumers the most direct contact with their food as possible. According to McClintock (2010), urban agriculture facilitates hands-on experience with human dependence on the biophysical environment, and reconnects urban dwellers not only with food, but also with manual labour. Studies from the Czech Republic and other countries confirm that this experiential aspect of urban gardening, which distinguishes it from other AFNs, is appreciated by gardeners. People grow fruits and vegetables because they like to have healthy, fresh food of known origin. A crucial condition, nonetheless, is that urban gardeners enjoy the activity of gardening (Jehlička et al., 2012; Sovová, 2015; Veen, 2015). Compared to people involved in other AFNs, urban gardeners interact with food and agriculture in a way that is more embodied (Pottinger, 2017), routinised (Veen, 2015) and unreflected 
(Sovová, 2015). At the same time, as recent research from the Czech Republic has demonstrated, gardens can contribute significantly to a households' food supply (Sovová, 2015; Vávra et al., 2018).

Despite its promising potential, however, food production seems to be the most disputed feature of the allotments. As Tornaghi (2016, p. 4) remarks, planning policies might accommodate urban gardens under the headings of leisure and community spaces, but their productive function is not easily accepted. The Czech experience confirms this observation: the ecological benefits of allotments as urban green spaces are generally acknowledged, as are their social and recreational functions. The potential of allotments for non-commercial food production, however, is largely omitted, even by their supporters (Sovová, 2015). We thus encounter a paradox: on one hand, urban dwellers are interested in food alternatives, but on the other hand, food production seems to be dismissed (by authorities) as unworthy of urban space.

\section{Research questions and methods}

This study focuses on the interplay between the rural and the urban as observed in urban allotments. Our principal question is: what manifestations of the rural and the urban (or their hybridisation) can be observed in urban allotments? Thus, we use the rural-urban lens to advance our understanding of urban allotments and, at the same time, to explore what these specific places can add to the broader discussion on rural-urban dynamics.

We investigated three specific aspects of urban allotments: (1) the physical environment of allotments; (2) the social relations in and around allotments; and (3) food production as a distinctive activity practised in allotments. These three topics ${ }^{5}$ guided our data collection and provided a structure for our analysis. In studying these three topical areas, we observed the manifestations of the urban and the rural in terms of: (1) materiality; (2) imaginary or meaning; and (3) practice (Cloke, 2006). With this operational design for the study, we approach the categories of urban and rural in a social-constructivist way, seeing them simultaneously as localities, images and ways of life (Halfacree, 2007).

\subsection{Research sample}

We conducted qualitative research in five localities spread around the city of $\mathrm{Brno}^{6}$ (see Fig. 1). Our choice of sites was aimed at capturing the diversity of allotments in Brno in terms of size, distance from the city centre, surroundings,

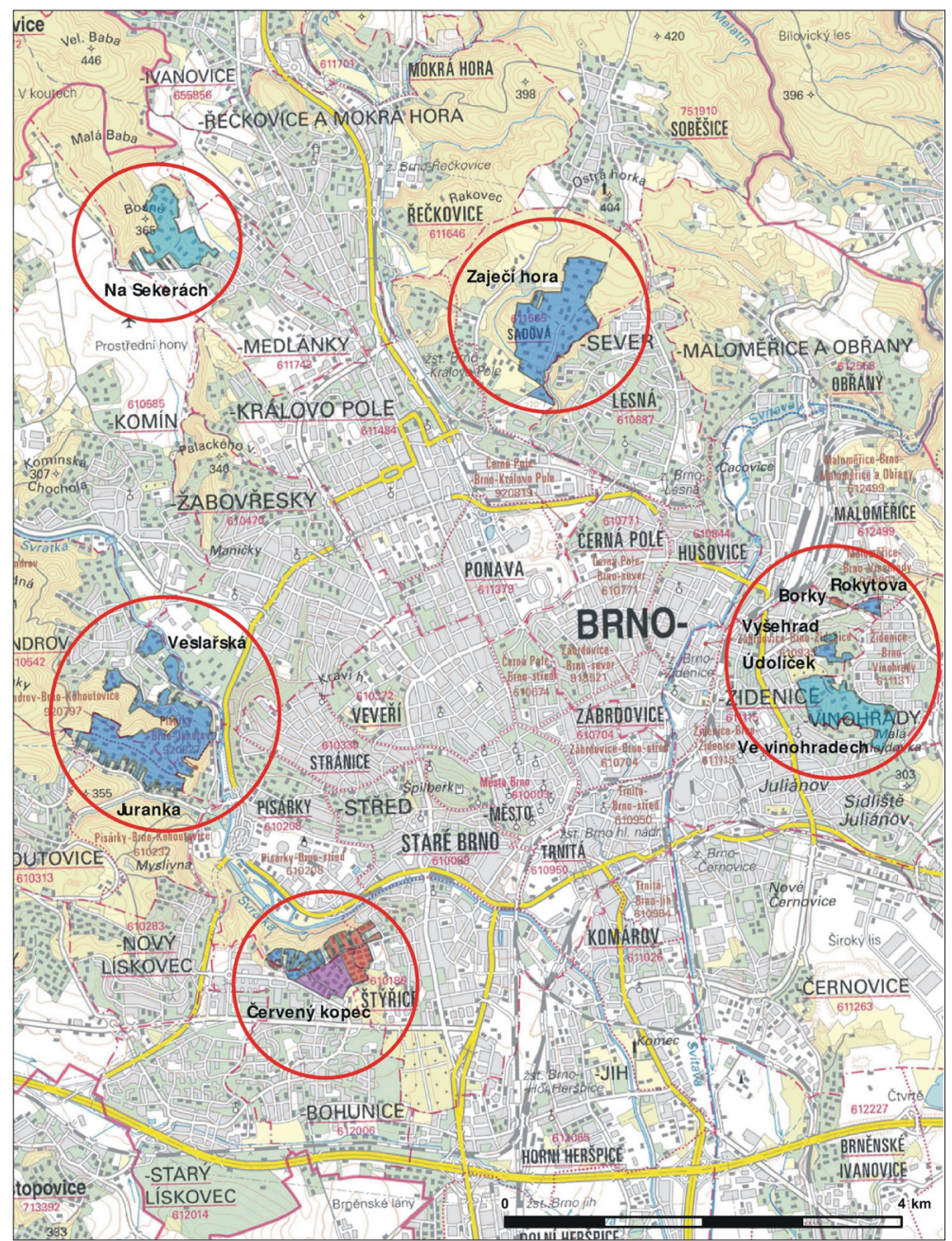

Fig. 1: Location of the research sites within the city of Brno

Source: Dostalík et al. (2017)

\footnotetext{
${ }^{5}$ The choice of these three aspects was based on the core functions of urban gardens, as described in Section 3, as well as our own research interests.

${ }^{6}$ The second largest city in the Czech Republic, with approximately 400,000 inhabitants.
} 
forms of ownership and administrative arrangements. Short descriptions of the research sites can be found in the Appendix 1.

The communication partners for interviews were recruited using a combination of methods. Our entry into the field was facilitated by 'gatekeepers', typically allotment representatives who introduced us to the gardening community and recommended suitable participants. We also used snowball sampling in which communication partners recommended other potential respondents. At later stages in our research, we used purposive sampling. Communication partners were chosen based on selected criteria in order to gain a more accurate picture of the diversity of allotment users and their practices ${ }^{7}$. Our final sample was thus composed of people of different ages, genders, marital statuses and incomes, who used their gardens in different ways and had varying statuses as members, or non-members of the Czech Union of Allotment and Leisure Gardeners ${ }^{8}$ including four allotment officials. Although the sample is not representative of the entire gardening community in Brno, we believe that it fairly reflects the diversity of gardeners in the selected allotments.

\subsection{Data collection}

Research was conducted in two waves. The first round of data collection took place from May to October 2016, and it included 17 semi-structured interviews ${ }^{9}$. We used an interview guide with 25 questions covering our three topics of interest. To study the physical environment of the allotments, we asked about the characteristics of the plots, ways of using the gardens and motivations for joining the allotment. In the section dedicated to social relations in and around the allotments, we discussed ownership, relations with neighbours, organised events and relations with the public and the authorities. To understand issues related to food production, we posed questions related to growing methods, variety and volume of crops and the importance of the gardens as a food source. We also discussed gifting and sharing networks, bringing together the topics of food production and social relations ${ }^{10}$. Interviews were complemented by participant and non-participant observation, which helped us to get acquainted with the field and to characterise the research sites.

The second round of data collection took place from March to November 2017 with the aim of refining, adding and validating data. It consisted mainly of participant and non-participant observations (about 12 field trips in total) ${ }^{11}$ and semi-structured interviews with nine communication partners. In this phase of the research, we concentrated more specifically on the social relations in the allotment gardens and their linkages to the materiality of the site. Our observations therefore focused on shared facilities within the allotments (rest-rooms, tools, notice boards) and places that might facilitate social interactions (common fireplaces, playgrounds, etc.) or hinder them (fences, inconvenient paths, etc.). In the realm of practices, we gathered information about social events in the allotments, relations with outsiders and the movement of people within the allotments. One of the authors participated in an event related to the turning-on of the water taps in the spring ${ }^{12}$, which allowed some insight into the social relations in the allotment and allowed for informal encounters and conversations with its members.

The interviews in the second round of data collection were also semi-structured but the interview guide was only used loosely as a checklist and we encouraged the communication partners to share their own narratives. Questions focused on gardeners' routines, relations with neighbours and social control, and the use of space. Some of the communication partners also provided us with a tour of the allotment or marked places of importance on a map.

\section{Results and discussion}

In this section we summarise the manifestations of the rural and the urban and their hybridisation in the areas of physical environment, social relations and food production that we identified in our data ${ }^{13}$. We contextualise our findings using relevant perspectives from the literature.

\subsection{Allotment gardens as non-urban environment}

The appearance of allotments is specific. All of our research sites allowed for small houses or garden sheds on the plots, but there were no norms regarding their appearance (other than a size limit). This resulted in a diverse mosaic of houses: from pre-fabricated to self-made, from sophisticated to frugal. The informality, do-it-yourself (DIY) and widespread use of all kinds of recycled materials (see Figs. 2 and 3) for garden sheds and other furnishings, creates a pastiche that reflects great care and creativity, and which confirms the role of the gardens for home- and place-making (Bhatti and Church, 2001), but which is not necessarily aesthetically pleasant.

\footnotetext{
${ }^{7}$ Our sample included 18 women and 12 men (including 6 couples that used the same plot and were interviewed together). Among the communication partners were 11 retired, 10 middle-aged and 9 younger gardeners. Four gardeners were rather productionoriented, and three used their gardens mostly for recreational purposes. Most of the participants used their plots for both food production and recreation. In nine cases, gardens played a more significant role in participants' lifestyles - garden houses were adapted for overnight stays and the communication partners spent a large part of their time there. One of the communication partners also used his plot for organising educational events.

${ }^{8}$ An association that administers most Czech allotments.

${ }^{9}$ Interviews from both rounds of data collection were recorded. We used the recordings and partial transcriptions during the analysis.

${ }^{10}$ We did not inquire directly (i.e. to participants) about the perception and construction of the allotments as urban or rural. This lens was only applied during the analysis.

11 The observations followed an open set of indicators, and they were complemented by taking photographs and recording GPS coordinates.

${ }^{12}$ Some of the allotments only had tap water from spring to autumn. Turning on the water thus marks the start of the gardening season, and most of the allotment members are present at this event.

${ }^{13}$ First, we analysed interviews and observation notes inductively, based on recurring topics. These were partly guided by the three areas we consider specific to urban allotments, but new topics also emerged. Second, we looked at the data through the lens of the rural, the urban and their hybridisation, searching for their manifestation in materiality, imaginary or meaning, and practice.
} 


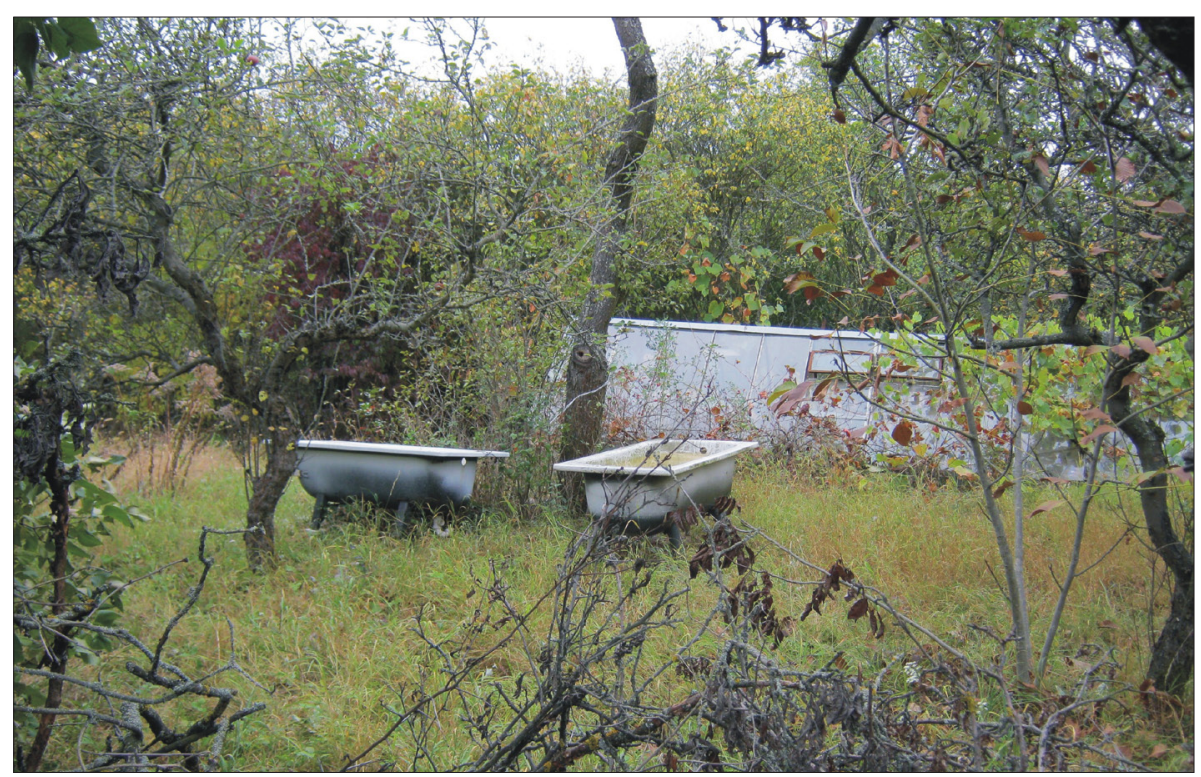

Fig. 2: Old bathtubs used for rainwater harvesting - similar DIY improvements can be both practical and picturesque, but they do not fit the image of neatly-maintained urban gardens (Photo: J. Dostalik)

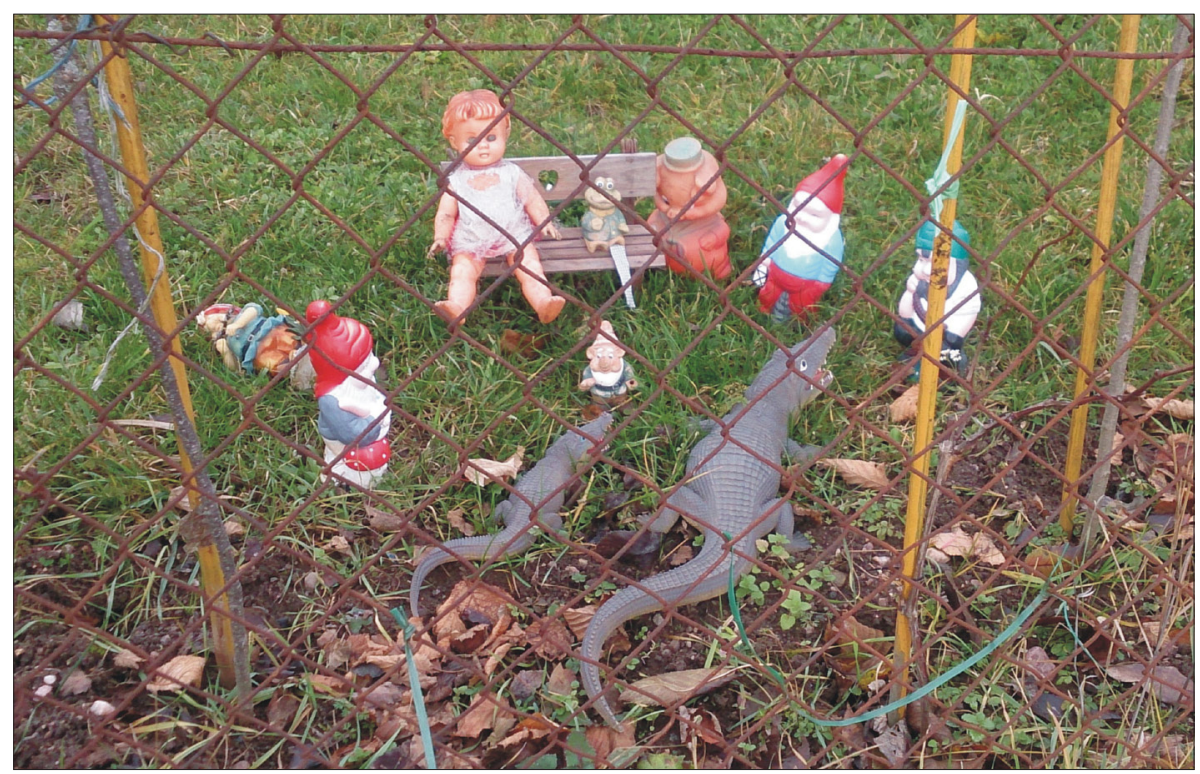

Fig. 3: Peculiar garden decorations are typical of the eclectic aesthetics of the allotments. (Photo: R. Krylová)

Appearance was a major point of criticism in some recent discussions about the future of Czech allotments. As documented by Kožešník (2018) and Gibas (2011), respectively, allotments were said to "resemble slums" or to be "ulcers on the face of the city". An official report on allotments commissioned by the municipality of Brno refers to compost heaps, a common part of the gardens, as "controversial (...) little waste dumps" (Ageris, 2006). These criticisms reveal a perception of the allotments as aesthetically inappropriate for the city, in other words, nonurban. Such argumentation is neither new, nor specific to the Czech Republic: for example, Borčić et al. (2015, p. 53) explain that during state socialism, Zagreb's illegal urban gardens were in stark contrast with its newly-constructed buildings, and thus, they also constituted a discursive opposite to the ideas of (socialist) modernity. Similarly, Djokić et al. (2017) state that although modernist planning visions for Belgrade emphasised contact with nature as a part of the modernisation process, urban gardens were often marginalised due to their association with rural areas ${ }^{14}$.

The opposition to the city is also marked by how gardeners use and perceive the allotments - both in relation to the physical environment and the lifestyle they entail. For example, one of our communication partners described her feelings after a longer stay in her garden as follows: "When I go to the theatre, I feel like a bushman; those nice clothes, you don't have to deal with them here [in the allotment]. You have the feeling that you go out to the big city when you leave this place."

One of the most common characteristics attributed to spending time in gardens was rest. Some communication partners connected it to the absence of noise, sometimes specifically to the absence of the sound of machines, radios

\footnotetext{
${ }^{14}$ Note the difference with socialist Czechoslovakia, where allotments were supported and integrated in urban planning (see Section 3.2).
} 
or cars: "If you want to build, you will be hammering, chopping wood, it will always make some minor noise, but it's about tolerance. But there are ten thousand cars in the city, and you cannot do anything about it." Others associated rest with solitude and privacy: "There is divine peace. If there was a path [through the allotment], that wouldn't be the case." Sometimes rest was perceived in opposition to modern technology and in connection to nature: "There is no electricity, but it does not matter to us. We're glad to hear birds in the summer; it's such peace." Gardens were thus seen as opposed to the modern city and rather close to nature, as we will elaborate later.

Communication partners also framed going out to the garden as an opposition to staying in their apartment (many of our communication partners live in high-rise apartment buildings). This was sometimes linked to former lifestyles: "We moved from a small town; in the city we would go crazy in the concrete, so we bought a garden", or similarly: "I come from the country, we had fields. We wanted to be outside, we wanted to have our good vegetables and fruits. And for the children, to get some fresh air." Some gardeners associated "going out" with health and exercise: "Without realising it, I'm doing it for health. The winter has always destroyed me, I ended up badly last year [...] It's really about getting the old guy out"15.

Another characteristic our communication partners associated with allotments was connection to nature. Gardeners spoke of reconnecting with nature and the land through plant cultivation. Some enjoyed feeding birds, which made them visit their garden at least twice a week even in winter. Whereas communication partners appreciated "nature", represented for instance by small animals (frogs, hedgehogs), wilder or bigger species that entered the gardens from the nearby forest were portrayed as a threat: "It was worse with the wild boar. If I had a gun, I would shoot it right away. It will do a lot of damage. That there's a hare, all right, you have to give that kind of tax to nature."

Other communication partners contrasted the gardens as cultivated places with the "wild" in terms of both nature and humans: "What's under the road towards the gardens, that's a jungle. It is a place of junkies, seedling scrub; if one does not eliminate it in the garden, nature takes over the garden in two years with everything; in four years the garden is lost, and there is a jungle. We have been reclaiming the garden out of this state for four years." With that, our sample reveals the ambiguity of experiencing nature, while at the same time appreciating a cultivated, safe leisure environment (Bhatti and Church, 2001).

To summarise, allotments are seen as non-urban spaces for different reasons, by the gardeners as well as outsiders. Whereas critics deem the appearance of allotments as inappropriate for the urban environment, gardeners appreciate the allotments' contrast with the concrete, rush and noise of the city. The non-urban character of the allotments was further related to what we could term the simplicity or informality of the allotment lifestyle - the absence of modern technologies, the irrelevance of dress codes, and so forth. This appreciation of a "simple life" echoes the narratives of voluntary simplicity, which can also be linked to migration to the countryside (Kala et al., 2016).

At the same time, allotments cannot be easily conceptualised as natural spaces. Gardeners might praise "being in nature" in their gardens but only as long as "nature" is cultivated and controlled. Allotments offer a mix of features: DIY sheds and vacant lots, overgrown with vegetation on the one hand, and sophisticated recreational features (i.e. swimming pools) and neatlymaintained flower beds on the other. In their materiality, perception and use these spaces are urban-rural or rather culture-nature hybrids.

\subsection{Allotments as new sociations?}

As indicated earlier, communication partners use their gardens for individual recreation, valuing the peaceful atmosphere and quiet surroundings. Despite this appreciation of rest and privacy, some gardeners also welcome the social life of allotments.

They expressed that when being "out" at the garden, they meet others more easily than in their homes in the city: "When we make coffee, we talk to our neighbours. It's kind of a social event, we say hello, we exchange a few words. In that [apartment] building, people are closing everybody behind their doors." This confirms the relevance of urban gardens for the development of social relations, which is documented in the literature (see section 3.2).

Communication partners reflected that the use of gardens is slowly changing. As we confirmed through our observations, gardens now provide recreation beyond cultivating plants: "Every fourth [garden] is only greenery, flowers, barbecues, just elders grow funny things, it [food growing] declines." Despite the slightly critical tone of this comment, other forms of recreation were highly valued among gardeners. 'Friends passing by', 'children playing', or 'neighbours having coffee together', were seen as integral parts of gardening.

When exploring the nature of social encounters in the allotments, we noticed that most were rather "private" gardeners would invite their family or friends to their plot, or they would meet in small groups with their garden neighbours. There often seemed to be strong relationships between neighbours, who help each other out, share surplus produce and seedlings, and so forth. These expressions of solidarity and conviviality, however, seemed to be mostly spontaneous: "Here the visits are not announced; they just sometimes come for tea. We don't meet regularly, but we see each other outside all the time, around work."

Similarly, mutual help and sharing appeared to be widespread, but situational and informal: "When I mow the grass, I usually mow a little bit to the left and a little bit to the right." The motivation behind these acts of kindness is related to a sense of togetherness based on a shared interest in gardening: "We had a lot of apricots, and I felt sorry to waste them, so I would offer them to people. At first people thought I would want something for it. So later they came by and brought me something else, to keep appearances. Or, when I had too many tomato seedlings. People were surprised that I gave them away for free. But well, I'm not gonna give them to people who come here to cultivate the garden for money. That's against my beliefs."

Contact between neighbours is facilitated by the physical layout of the allotments - many (although not all) of our research sites did not have fences separating individual plots, which can be interpreted as a sign of trust among members of the gardening community. In a few cases, communication partners commented upon the intense

\footnotetext{
15 See also Wang and MacMillan (2013) who elaborate on the health benefits of gardening, particularly for the elderly.
} 
contact between neighbours with a more critical tone: they viewed it as a source of social control that leads to a loss of privacy. Even communication partners who viewed their neighbours as slightly intrusive, however, mentioned some benefits of neighbourly relations, such as a feeling of safety or knowledge exchange.

Whereas allotments have a vibrant social life in terms of informal encounters and relations, official social events attended by all allotment members are rare. Some communication partners expressed slight nostalgia for the past, when these types of communal events were organised more often: "There used to be trips, there used to be a rose exhibition, but everybody is old now and no one wants to do it. Three or four times a year, [we do] communal work, but not these events. The [allotment] representatives are getting older and the young ones are not interested in socialising"; or "I think the times have changed, people do not socialise this way, they socialise with their family, they prefer their family and friends."

Nonetheless, the communal character of gardens was indicated by the number of places for formal and informal information exchange in the allotments, such as bulletin boards next to entrances (see Fig. 4) and information boards on fences and gates. These boards demonstrate that even in localities with weak official organisational structures there is the will or need to communicate and exchange information among community members. In that sense, the allotments in our study could be categorised as interest-based (rather than place-based) communities (Veen, 2015). While people appreciated the social life in the allotments, their main motivation to join was the activity of gardening itself, rather than establishing new social relations. As a result, the allotments facilitated social encounters, but these relationships typically did not extend beyond the space of the allotments.

We conclude this section by mentioning the linkages of the allotments to their surroundings. Through observation, we obtained data regarding the permeability of each site. All of the localities are used for walks and are interwoven with a number of paths used primarily by those who know the localities well. At the same time, allotments also feature relatively large enclosed enclaves, separated from public paths by locked passages that prevent public use (see Fig. 5). Thus, the allotments are attractive areas for public recreation, and the proximity of forests, local hiking trails and natural sites near some of the researched sites (which add to their non-urban character) make them even more appealing. The gardeners do wish to keep a certain level of privacy and security, however, which can be interpreted as a sign of the privatisation of these spaces (for a more nuanced discussion of a similar situation, see Koopmans et al., 2017).

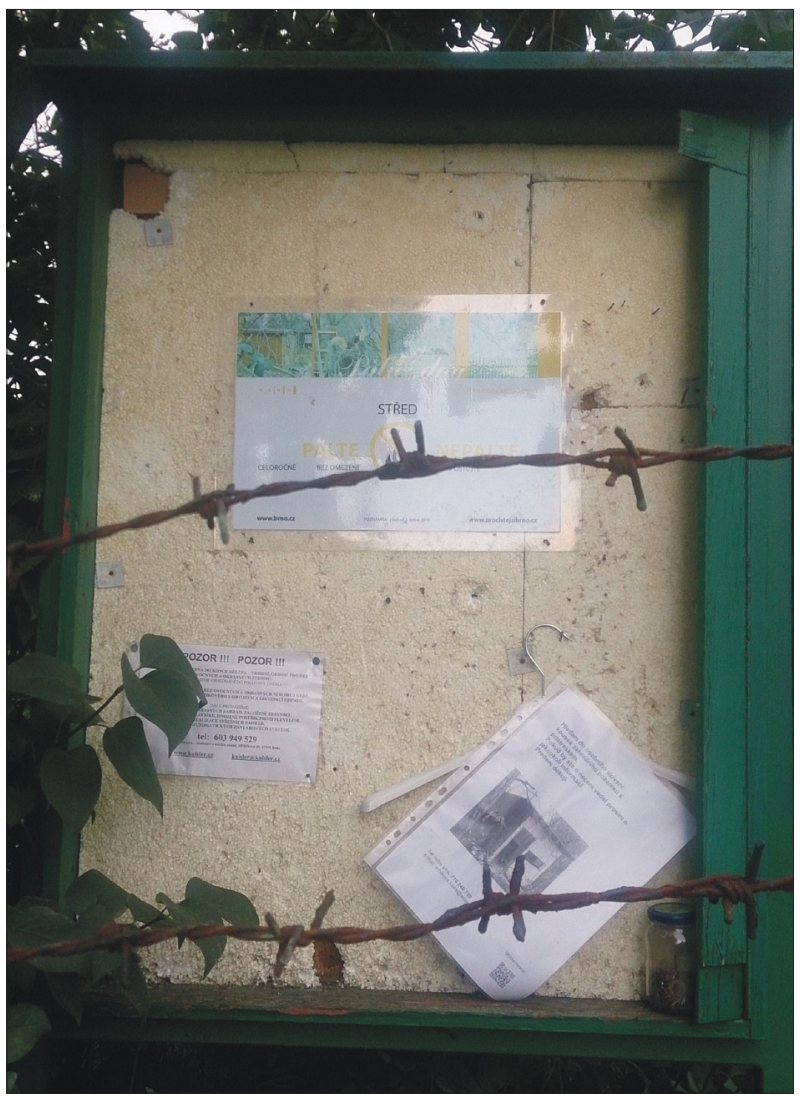

Fig. 4: Notice boards still play an important role in internal communications in allotment gardens (Photo: R. Krylová)

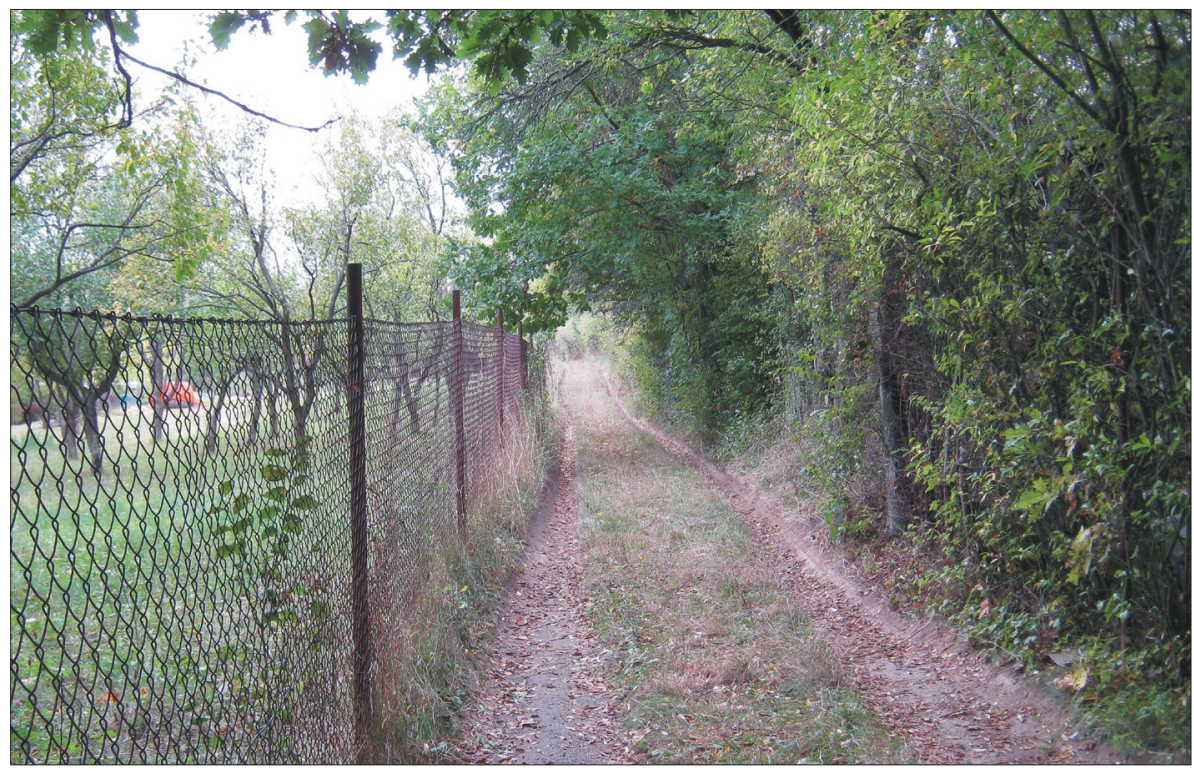

Fig. 5: The areas around allotments are used for walks, but the gardens themselves are closed to the public (Photo: J. Dostalík) 
At the same time, DIY repairs and beautification, which typically contribute to the appearance of allotments (see above), sometimes spread over garden fences and into surrounding areas. These activities can be interpreted as an expression of the gardeners' interest in their surroundings beyond their private spaces. The material character of the study sites thus reveals the hybrid character of allotment gardens, which are at the same time public, private and community spaces. Some communication partners were aware of the advantages brought by their voluntary efforts, which benefitted not only their families or the community but also the public: "Families with children or the elderly, while using their free time, are doing something and keeping the garden, so it's still better than if the city had to make a park, cover it with grass and then maintain it for a lot of money." In this way, the materiality of the gardens can be seen as enhancing the liveability of the neighbourhood also for residents who are not involved in the allotments, as suggested by Veen (2015).

In summary, although our communication partners perceived their gardens as more suitable for socialising than elsewhere in their urban environment, we see the influence of individualisation in the allotments in weakening social ties and a preference for privacy. At the same time, the weakening of formal ties and the strengthening of informal ones suggest that the social groups we studied have some features of new sociations, in which solidarity and conviviality arise based on shared goals but in which relationships are not necessarily binding (Macnaghten and Urry, 1998, p. 27). Our findings thus align with Novák's picture of some allotment gardens as places which can cultivate not only vegetables, but also identity, community and civility (Novák, 2013, p. 21).

\subsection{Food production as an integral part of life}

A recent nationally representative survey on food selfprovisioning in the Czech Republic (Vávra et al., 2018) showed that food production remains an integral part of people's use of land. Of the 818 respondents who reported to have access to a garden, an orchard or a similar type of agricultural land (40\% of the survey participants), 775 used the land to produce some food (38\% of the survey participants (Vávra et al., 2018). Our case study confirms these findings on the micro-level, while also supporting the observations of Gibas et al. (2013) from Prague allotments, where plots are used for both cultivation and other forms of recreation.

The gardens of all our communication partners include vegetable beds and/or fruit trees and bushes, but most of them also feature signs of other recreational uses, such as swimming pools, grills, outdoor seating, and playgrounds for children (see Fig. 6). Gardeners did not see the recreational and productive functions of allotments as contradictory but as interconnected and in fact inseparable. All communication partners perceived gardening and food production as a hobby, something they "enjoyed" but "did not do for living". This finding is consistent with the observations of Jehlička et al. (2012), who noted that the most important motivation for food self-provisioning is pursuing a hobby, followed by acquiring healthy and fresh food.

In our sample, home-grown food was valued for its qualities, which were commonly juxtaposed with conventional produce (referred to as "what you can buy in the shop"). The latter is described as "chemical" and "tasteless", whereas gardeners' own produce "is not sprayed" and "you know what you put in it". In the eyes of our communication partners, the transparent origin of home-grown food is linked to its freshness, healthiness and better taste, which "cannot compare" to that of fruits and vegetables from other sources. The appreciation of homegrown food is consistent with existing literature from the Czech Republic (Jehlička et al., 2012) and elsewhere (Kortright and Wakefield, 2011; Veen, 2015).

The construction of the value of home-grown food, however, seems to go beyond its sensory qualities and into more embodied and affective realms (McClintock, 2010; Pottinger, 2017). The fact that gardeners interact with produce by investing their time, skill sets and physical work in it is - at least for some of our communication partners not only a guarantee of the transparent origin of their food, but a value in itself. As one of the gardeners put it: "it makes one feel better, to have one's own." Similarly, our informants' criticism of conventional produce was not only concerned with the use of pesticides and fertilisers, but it also reflected a sense of alienation from more traditional ways of food production and a criticism of 'over-technologisation': "If you look at the mass-production sites... What you buy in the

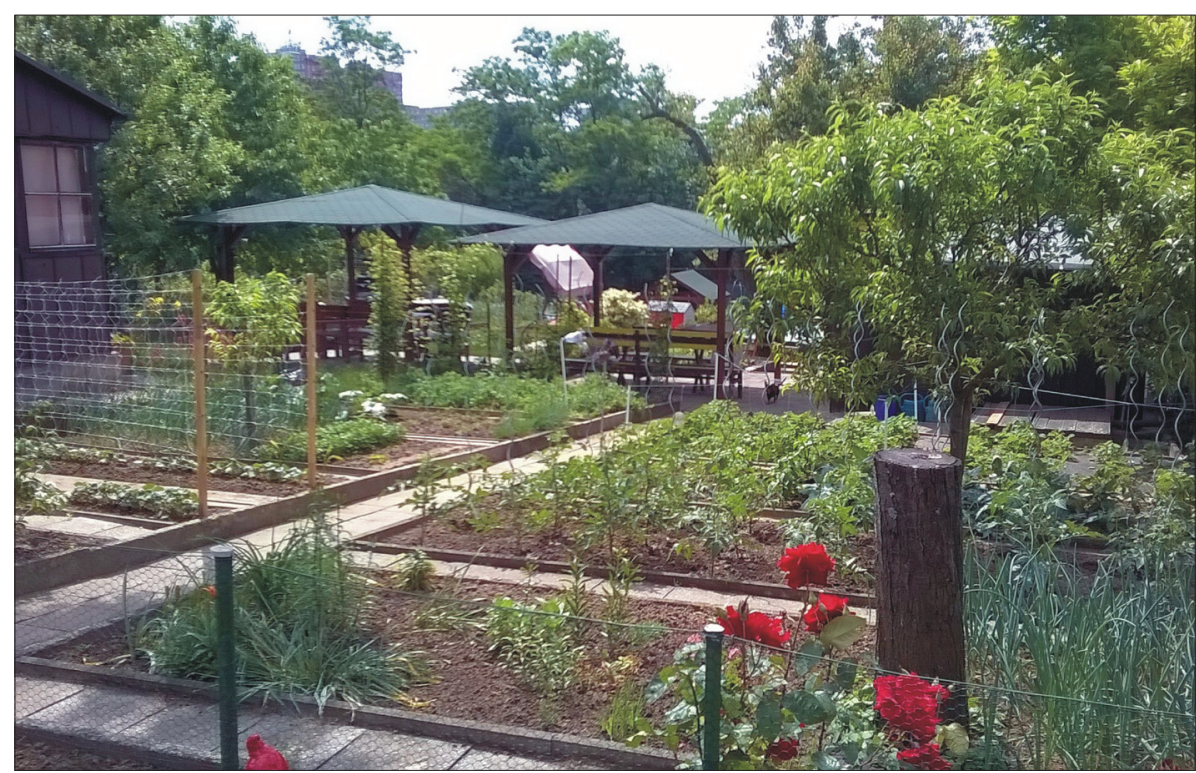

Fig. 6: Most plots in the studied areas combined productive, ornamental and recreational elements (Photo: L. Kala) 
shops today has not even seen a field; it grows in a fiberglass cube with a drip of water and a chemical compound of fertilisers. And you can recognise that on the tomato."

When deciding on which crops to grow, gardeners tend to be pragmatic, considering the returns on their work and the quality of produce they could harvest compared to the quality of fruits and vegetables they could obtain from other sources. For instance, gardeners are less likely to grow crops that are available in the market for a low price - especially if such crops are (perceived as) difficult to grow and the (perceived) difference in quality is low. Contrarily, when the quality of home-grown and store-bought produce differs significantly, economic considerations are left aside: "Root crops I buy. It doesn't pay off [to grow them], price-wise. Peas you can also buy, but they are always better home-grown. With tomatoes, the difference is remarkable. I don't buy a tomato in winter. My tomatoes might be there only three months a year, but I try to make preserves for the winter, so I have them all year and I don't have to buy them in a shop." This quote shows that gardens are perceived as a suitable source of some crops but the practice of growing your own is not overly romanticised.

Despite their strong opinions about conventional food production, most of our communication partners cannot be categorised as conscious consumers. For instance, the term organic was often used half-jokingly to describe homegrown produce, whereas certified organic goods were seen as overpriced or even fraudulent: "I don't buy organic food because there is no such thing as organic food. I come from a village; I know how it goes. My parents used to grow vegetables a lot, so I'm aware that if you don't spray it, it simply won't grow. The organics, that is only a matter of fashion."

Self-provisioning was not motivated by the desire to obtain food in a sustainable way, confirming previous observations about Czech gardeners (Jehlička et al., 2012; Sovová, 2015) and contributing to ongoing discussions about gardening as an environmentally conscious practice (e.g. Tornaghi, 2011; Veen, 2015). Gardeners' critical attitudes towards conventional "chemical" produce might lead to the assumption that their gardening methods are strictly organic. Although most gardeners in our sample had negative attitudes towards agrochemicals, some felt that their use was necessary because pests spread easily within the allotments from one plot to another. Whereas some gardeners are open to inspiration from alternative growing methods, such as permaculture or organic agriculture, others perceive them as suspicious novelties.

This brings us to an important point in our case: our informants' gardening skills and their attitudes towards gardening. Our communication partners were mostly experienced gardeners with broad knowledge about and skills in food growing, as well as other practices related to the produce, such as cooking, storing and preserving, and other gardening-related activities, such as small repairs and DIY. Many of our communication partners mentioned being involved in gardening since childhood, whether in urban allotments or in former home gardens, which in some cases were located in the countryside. Consequently, they perceived food growing as an integral part of their lives. Garden visits were well integrated in their daily routines, and therefore garden produce was easily incorporated into their food provisioning and meal planning (see also Veen, 2015).
Some gardeners liked to educate themselves (e.g. by following television shows and magazines about gardening) and experiment. Innovations spread easily through informal knowledge sharing. Especially for older allotment members, though, the core of their skills seemed deeply ingrained and routinized and largely taken for granted: knowing how to grow food was a matter of common sense. This is in stark contrast with the recent concern about deskilling in matters of food, which some communication partners also expressed. Statements such as: "The kids nowadays don't even know how carrots are grown" were not uncommon, and some gardeners used their plots to educate their children and grandchildren about gardening ${ }^{16}$

The hybridisation of food-growing practices can be seen on several levels. Our communication partners engaged in food production as a natural and routinized part of their lives, guided by a down-to-earth logic, rather than as a result of conscious deliberation or an activist agenda typically linked to alternative food networks. But at the same time, they did not produce food for their livelihoods; without exception they referred to gardening as their hobby, albeit one with a strong influence on their lifestyle and identity. Furthermore, we have shown that the narrative of home-grown food as being better than conventional produce is not free of internal contradictions.

\section{Conclusions}

Urban gardens have always been at the intersection of the rural and the urban. Established to facilitate the transition of rural workers to the industrial city, these spaces have become a reminder of the incompleteness of the urbanisation process. Borčić et al. (2015, p. 53) use the term heterotopia to describe urban gardens as places that differ from the dominant (urban) environment and which are marginalised for their association with the countryside (see section 5.1).

Similar perspectives, which implicitly refer to modernist categories of the urban and rural, resonate throughout contemporary discussions about the future of allotments in the Czech Republic and elsewhere in the world. With advancing urbanisation, allotments have faced increasing pressure as they are often located on lucrative land suitable for development (for a description of the situation in the Czech Republic and Slovakia, see Tóth et al., 2018). In an example described by Gibas (2011), the claim that urban allotments "do not belong in the modern city" was used as an argument to abolish allotment gardens in Prague and to replace them with a public park - a form of greenery deemed more appropriate for the urban context. Not only are urban gardens viewed as "rural", but - as we mentioned in the theoretical section of this paper - the rural is implicitly seen as inferior (Plüschke-Altof, 2016). On that account, urban gardens are still commonly pushed to "the cracks of the system", as Tornaghi (2016) pointed out.

Our research confirms that allotments are indeed perceived as being distinctive from the city and are used accordingly. Notably, the features of allotments that are 'commonsensically' viewed as non-urban were also the most appreciated by our communication partners. The allotments were described as peaceful and quiet in contrast to the hectic city. Furthermore, they facilitated social interactions unlike the anonymous urban environment, and provided an opportunity to reconnect with one's food production, in

${ }^{16}$ See Hake (2017) for an overview of the use of gardens for intergenerational learning 
contrast to the alienation of the conventional food system. This discursive but also physical and lived construction of the allotments forms a parallel to counterurbanisation as criticism of the urban and renewed interest in the rural. Broadening the use of the term, we therefore suggest that the increasing interest in urban gardening could be conceptualised as "intraurban counterurbanisation", that is, an "escape from the city" within its own boundaries.

Borčić et al. (2016, p. 55) describe the gardeners of socialist-era Zagreb as a "hybridised class of "urban bodies with rural souls' whose socio-economic identity is urban, but whose socio-cultural identity is still deeply rural". Our findings defy such an elegant image: the materialities, narratives and practices we encountered in Brno allotments exhibited some characteristics that would commonsensically be associated with rural (or at least non-urban) settings. They were, nonetheless, inseparably intertwined with other influences that are stereotypically urban (or at least nonrural). Indeed, as Andersson et al. (2016, chap. 1) note, counterurbanisation cannot be understood as a simple return to the rural, but rather as a case of urban-rural hybridisation, an eclectic mix of features associated with both cities and the countryside.

To summarise, we have drawn two conclusions from our research. First, our study of urban allotments adds to the body of literature documenting the dynamic changes of the urban and the rural. Within this field, scholars have mostly studied changes in the countryside resulting from migration to and from rural areas, the dissemination of urban lifestyles and cultures, and related socioeconomic developments. Our contribution focuses instead on the rural-urban dynamics within the city. Our constructivist approach allows us to trace these dynamics not necessarily in terms of major demographic trends or physical changes, but rather in terms of perceptions, practices and micro-level adjustments. It also allows us to challenge the rural-urban dichotomy, which our data demonstrate to be an oversimplification.

The rural-urban perspective adds a new angle to some of the discussions about urban gardens: it deepens our understanding of why urban gardens are attractive for urban dwellers, and at the same time, why it can be challenging to accommodate gardening in urban planning schemes. The case of allotments adds yet another crack to the modernist rural-urban dichotomy. In our second conclusion, we therefore add our voices to authors who call for a break of these categories, which no longer serve to accurately describe the realities we inhabit. We believe that overcoming the outdated constructs of the city and the countryside and acknowledging urban gardens as a specific type of space, could help legitimise allotments in the eyes of planners and policymakers, and hence open new possibilities for making our towns and cities more liveable.

\section{Acknowledgements}

Work on this paper was supported by the Czech Technological Agency project: "Development of Methodology for Assessment of Areas of Urban and Garden Production" (TD03000345). We would like to thank our project colleagues for the photographs used in this paper.

\section{Appendix 1: Descriptions of the research sites}

Zaječí hora is located on the city's outskirts, but is easily accessible by public transport. The allotment is surrounded by a forest, which provides a pleasant and calm environment, but also presents a threat in the form of wild animals. Although most plots are privately owned, the entire allotment is part of the Czech Union of Allotment and Leisure Gardeners. The gardens are diverse, including extensive orchards as well as intensive vegetable production; some gardeners even raise animals.

The Na Sekerách allotment lies on the city's outskirts, in the vicinity of an airport. Most of the plots are privately owned, and there is a gardeners' association independent of the Czech Union of Allotment and Leisure Gardeners. Most gardens are managed rather extensively, and there is a community of people interested in permaculture and natural gardening methods. Part of the allotment does not have access to water other than collected rainwater, which influences crop composition.

Červený kopec is located on a hill in the city centre on the site of a former brick factory. Remnants of bricks and other building materials are present in the soil, lowering its quality. More than half of the area is rented via the local branch of the Czech Union of Allotment and Leisure Gardeners, which has the land in short-term lease from the city. This situation creates insecurity about future access to land. The plots are rather homogeneous in terms of size and appearance.

The Jundrov allotment is situated outside the city centre between a river and a row of houses and is thus inaccessible to outsiders. The area is difficult to access via public transport. Land ownership is mixed; plots belong to individual gardeners, other actors, and the city. The allotment is part of the Czech Union of Allotment and Leisure Gardeners. The gardens are mostly managed in an intensive way.

Židenice is an allotment consisting of five different sections located in the same neighbourhood that differ somewhat in their characteristics. One of the sections consists of large, privately owned and extensively managed plots. Two other sections we included in our sample fall under the Czech Union of Allotment and Leisure Gardeners. Plots here are privately owned (by gardeners and other actors who rent the plots); they are smaller and managed more intensively than gardens in the first section. The small amount of plots within these allotments contributes to closer communities.

\section{References:}

AGERIS (2006): Vyhodnocení zahrádkářských lokalit na území města Brna. Brno, Ageris.

ALLEN, A. (2003): Environmental Planning and Management of the Peri-Urban Interface: Perspectives on an Emerging Field. Environment and Urbanization, 15(1): 135-148.

ANDERSSON, K., SJÖBLOM, S., GRANBERG, L., EHRSTRÖM, P., MARSDEN, T. [eds.] (2016): Metropolitan Ruralities. Bingley: Emerald Group Publishing Limited.

BELLOWS, A. C. (2004): One hundred years of allotment gardens in Poland. Food \& Foodways, 12: 247-276.

BERRY, B. J. L. [ed.] (1976): Urbanization and CounterUrbanization. Urban Affairs Annual Reviews, Vol. 11. Beverly Hills, CA, Sage Publications.

BHATTI, M., CHURCH, A. (2001): Cultivating Natures: Homes and Gardens in Late Modernity. Sociology, 35(2): 365-383.

BORČIĆ, L. S., CVITANOVIĆ, M., LUKIĆ, A. (2016): Cultivating alternative spaces - Zagreb's community 
gardens in transition: From socialist to post-socialist perspective. Geoforum, 77: 51-60.

BREUSTE, J., ARTMANN, M. (2014): Allotment Gardens Contribute to Urban Ecosystem Service: Case Study Salzburg, Austria. Journal of Urban Planning and Development, 141(3): A5014005.

CLOKE, P. (2006): Conceptualizing Rurality. In: Cloke, P., Marsden, T., Mooney, P. [eds.]: Handbook of rural studies (pp. 18-28). London, SAGE.

CHAMPION, T. (2001): Urbanization, Suburbanization, Counterurbanization and Reurbanization. In: Paddison, R. [ed.]: Handbook of Urban Studies (pp. 143161). London, SAGE.

DELGADO, C. (2017): Mapping urban agriculture in Portugal: Lessons from practice and their relevance for European post-crisis contexts. Moravian Geographical Reports, 25(3): 139-153.

DJOKIĆ, V., RISTIĆ TRAJKOVIĆ, J., FURUNDŽIĆ, D., KRSTIĆ, V., STOJILJKOVIĆ, D. (2017): Urban garden as lived space: Informal gardening practices and dwelling culture in socialist and post-socialist Belgrade. Urban Forestry \& Urban Greening, 30: 247-259.

DUFFKOVÁ, J. (2002): První a druhý domov. Vývoj české záliby $\mathrm{v}$ chataření a chalupaření $\mathrm{z}$ pohledu sociologie. Př́tomnost, 2: 29-31.

DUŽÍ, B., FRANTÁL, B., SIMON ROJO, M. (2017): The geography of urban agriculture: New trends and challenges. Moravian Geographical Reports, 25(3): 130-138.

GANDY, M. (2010): Vicissitudes of urban nature: transitions and transformations at a global scale. Radical History Review, 107: 178-184.

GIBAS, P. (2011): Falešná zeleň a rajské zahrady. A2 19: 12 13 [online]. Available at: http://www.advojka.cz/ archiv/2011/19/falesna-zelen-a-rajske-zahrady

GIBAS, P., MATĚJOVSKÁ, L., NOVÁK, A., ROLFOVÁ, E., TVARDKOVÁ, V., VALEŠOVÁ, I., VESELÝ, M. (2013): Zahrádkářské osady: Stíny minulosti, nebo záblesky budoucnosti? Prague, Faculty of Humanities, Charles University.

GRANBERG, L. (2016): Long Wave of Rural Research from Combating Poverty to Sustaining Ecosystems. In: Andersson, K., Sjöblom, S., Granberg, L., Ehrström, P., Marsden, T. [eds.] (2016): Metropolitan Ruralities (pp. 68-91). Bingley, Emerald Group Publishing Limited.

HAASE, D. (2008): Urban Ecology of Shrinking Cities: An Unrecognized Opportunity? Nature and Culture, 3(1): 1-8. DOI:10.3167/nc.2008.030101.

HAKE, B. J. (2017): Gardens as Learning Spaces: Intergenerational Learning in Urban Food Gardens. Journal of Intergenerational Relationships, 15(1): 26-38.

HALFACREE, K. (2007): Trial by space for a 'radical rural': Introducing alternative localities, representations and lives. Journal of Rural Studies, 23: 125-141.

HORLINGS, L. G., MARSDEN, T. (2014): Exploring the 'New Rural Paradigm' in Europe: Eco-economic strategies as a counterforce to the global competitiveness agenda. European Urban and Regional Studies, 21(1): 4-20.
JEHLIČKA, P., KOSTELECKÝ, T., SMITH, J. (2012): Food Self-Provisioning in Czechia: Beyond Coping Strategy of the Poor: A Response to Alber and Kohler's 'Informal Food Production in the Enlarged European Union' (2008). Social Indicators Research, 111(1): 219-234.

KALA, L., GALČANOVÁ, L., PELIKÁN, V. (2016): Residential Preferences in the Context of Voluntary Simple Lifestyles: What Motivates Contemporary Czech Simplifiers to Reside in the Countryside? Human Affairs, 26(4): 410-421.

KESHAVARZ, N., BELL, S. (2016): A history of urban gardens in Europe. In BELL, S. et al. [eds.]: Allotment Gardens in Europe (pp. 8-33). New York, Routledge.

KLVAČ, P., ULČÁK, Z. (2008): Samozásobitelství potravinami - může být život na venkově luxusní? In: Dreslerová, J. [ed.]: Venkovská krajina 2008. Conference Proceedings (pp. 48-51). Hostětín: Veronica.

KLVAČ, P. (2013): Venkov v hlavním městě. Sedmá generace 22(4): 42-43.

KOOPMAS, M. E., KEECH, D., SOVOVÁ, L., REED, M. (2017): Urban agriculture and place-making: Narratives about place and space in Ghent, Brno and Bristol. Moravian Geographical Reports, 25(3): 154-165.

KORTRIGHT, R., WAKEFIELD, S. (2011): Edible backyards: a qualitative study of household food growing and its contributions to food security. Agriculture and Human Values, 28: 39-53.

KOŽEŠNÍK, M. (2018): Český zahrádkářský svaz - Územní sdružení Praha-město. Presentation at Praha \& Př́roda - Urban Gardening. Centre for Architecture and Metropolitan Planning, 19. 4. 2018, Prague.

LEFEBVRE, H. (1996): Writings on Cities. Oxford, Blackwell.

LIBROVÁ, H. (2010): Individualizace v environmentální perspektivě: sociologické rámování mění pohled a plodí otázky. Sociologický časopis/Czech Sociological Review, 46(1): 125-152.

MACNAGHTEN, P., URRY, J. (1998): Contested Natures. London, Thousand Oaks, CA, SAGE Publications.

MCCLINTOCK, N. (2010): Why farm the city? Theorizing urban agriculture through a lens of metabolic rift. Cambridge journal of regions, Economy and Society, 3(2): 191-207.

MITCHELL, C. J. A. (2004): Making sense of counterurbanization. Journal of Rural Studies, 20: 15-34.

MOUGEOT, L. J. A. (2000): Urban Agriculture: Definition, Presence, Potentials and Risks, and Policy Challenges. Ottawa, International Development Research Centre.

NOVÁK, A. (2013): Zahrádkářské osady v reflexivní modernitě: sociologická reflexe. In: Gibas, P. et al. (2013): Zahrádkové osady: stíny minulosti nebo záblesky budoucnosti? (pp. 13-26). Prague, Faculty of Humanities, Charles University.

NILSEN, M., BARNES, B. M. (2014): The Working Man's Green Space: Allotment Gardens in England, France, and Germany, 1870-1919. Charlottesville, University of Virginia Press.

OKVAT, H. A., ZAUTRA, A. (2011): Community Gardening: A Parsimonious Path to Individual, Community, and Environmental Resilience. American Journal of Community Psychology, 47(3-4): 374-387. 
OUESLATI, W., ALVANIDES, S., GARROD, G. (2015): Determinants of Urban Sprawl in European Cities. Urban Studies, 52(9): 1594-1614.

OVERTON, J., MURRAY, W. E. (2016): Fictive place. Progress in Human Geography, 40(6): 794-809.

PLÜSCHKE-ALTOF, B. (2016): Rural as periphery per se? Unravelling the discursive node. Sociální studia/Social Studies, 13(2): 11-28.

POTTINGER, L. (2017): Planting the seeds of a quiet activism. Area, 49(2): 215-222.

RENTING, H., MARSDEN, T., BANKS, J. (2003): Understanding alternative food networks: exploring the role of short food supply chains in rural development. Environment and Planning, 35(3): 393-411.

RUMPEL, P., SLACH, O. (2012): Je Ostrava 'smrštujícím se městem'? Sociologický časopis/Czech Sociological Review, 48(5): 859-878.

SCHMELZKOPF, K. (2002): Incommensurability, Land Use, and the Right to Space: Community Gardens in New York City. Urban Geography, 23(4): 323-343.

SIMMS, A. (2008): Nine Meals from Anarchy: Oil dependence, climate change and the transition to resilience. London, New Economics Foundation.

SOVOVÁ, L. (2015): Self-provisioning, Sustainability and Environmental Consciousness in Brno Allotment Gardens. Sociální Studia/Social Studies, 12(3): 11-26.

SÝKORA, L. (2014): Proměny postsocialistických metropolí. Geografické rozhledy, 23(4): 2-5.

ŠIMON, M., BERNARD, J. (2016): Rural Idyll without Rural Sociology? Changing Features, Functions and Research of the Czech Countryside. Eastern European Countryside, 22(1): 53-68.

TORNAGHI, C. (2014): Critical geography of urban agriculture. Progress in Human Geography, 38(4): 551-567.
TÓTH, A., TIMPE, A. (2017): Exploring urban agriculture as a component of multifunctional green infrastructure: Application of figure-ground plans as a spatial analysis tool. Moravian Geographical Reports, 25(3): 208-218.

TÓTH, A., DUŽÍ, B., VÁVRA, J., SUPUKA, J., BIHUŇOVÁ, M., HALAJOVÁ, D., MARTINÁT, S., NOVÁKOVÁ, E. (2018): Changing Patterns of Allotment Gardening in the Czech Republic and Slovakia. Nature and Culture, 13(1): 161-188.

UNITED NATIONS POPULATION FUND (2007): State of world population 2007: Unleashing the Potential of Urban Growth. Available at: http://www.unfpa.org/sites/ default/files/pub-pdf/695_filename_sowp2007_eng.pdf

VAN VEENHUIZEN, R. [ed.] (2006): Cities Farming for the Future - Urban Agriculture for Green and Productive Cities. Ottawa, RUAF Foundation, IDRC and IIRR Publishing.

VASANTKUMAR, C. (2017): From world cities to world sites: Strategic ruralism and the case for an anthropology of actually existing connectivity. Critique of Anthropology, 37(4): 364-382.

VÁVRA, J., DANĚK, P., JEHLIČKA, P. (2018): What is the contribution of food self-provisioning towards environmental sustainability? A case study of active gardeners. Journal of Cleaner Production, 185: 1015-1023.

VEEN, E. (2015): Community gardens in urban areas: A critical reflection on the extent to which they strengthen social cohesion and provide alternative food. Doctoral Thesis. Wageningen, Wageningen University.

VOLENÍKOVÁ, L. (2014): Community Based Urban Agriculture in Southern Africa: Case Study of Ndola, Zambia. Master's Thesis. Olomouc, Palacký University.

WANG, D., MACMILLAN, T. (2013): The benefits of gardening for older adults: a systematic review of the literature. Activities, Adaptation \& Aging, 37(2): 153-181.

Please cite this article as:

SOVOVÁ, L., KRYLOVÁ, R. (2019): The countryside in the city? Rural-urban dynamics in Brno, Czech Republic. Moravian Geographical Reports, 27(2): 108-121. Doi: 10.2478/mgr-2019-0009. 